\title{
Pensamento e invenção: por uma formação outra
}

\author{
Thought and invention: for an other formation
}

\author{
Rosimeri de Oliveira Dias; Heliana de Barros Conde Rodrigues \\ Universidade do Estado do Rio de Janeiro
}

\section{RESUMO:}

O artigo expõe análises das pesquisas-intervenção realizadas com formação e com estudos foucaultianos na Universidade do Estado do Rio de Janeiro. Cartografa movimentos que nos desprendem dos exercícios de poder, servindo de reveladores para as transformações do sujeito. Para tanto, traz três dispositivos. Primeiro, as linhas tecidas no dispositivo aula, recorrendo ao curso A Hermenêutica do Sujeito, de Michel Foucault, e colocando em pauta a anarqueologia como atitude prática para pensar/fazer uma formação que se desvincule de pedagogias capacitadoras. Em seguida, as linhas do dispositivo se delineiam por meio de entrevistas e de alguns escritos de intercessores de Foucault para indagar se a formação perspectivada pela invenção pode ser uma formação outra, problematizadora. Em um terceiro momento, apresentam-se estratégias singulares de formar professores que privilegiam práticas éticas e políticas regulares e trabalhos dotados de continuidade, porém sem efeitos de coerção.

Palavras-chave: formação inventiva de professores; pesquisa-intervenção; Michel Foucault.

\section{ABSTRACT:}

This article showcases analyses of the research intervention done with formation and Foucaultian studies at the Universidade do Estado do Rio de Janeiro. It maps the movements that detach us from exercises of power, serving as revealers to the transformation of the subject. Therefore, it brings three devices. First, the lines woven on the class device, resorting to Michel Foucault's course The Hermeneutics of the subject and driving atention to anarchaeology as a pratical attitude to think/do a formation that is unlinked from training pedagogies. Next, the lines of the devices shape themselves by interviews and some writings of Foucault intercessors to ask if formation under the perspective of invention can be an formation other, a problematizing one. In a third moment, singular strategies of teachers formation are presented, they favor regular ethical and political practices and works with continuity, yet without effects of cohersion.

Key-words: inventive teachers formation; research-intervention; Michel Foucault.

DOI: 10.12957/mnemosine.2020.52676

\section{Introdução}

Apesar de todas as contestações existentes, muitas das quais provenientes de autores que serão citados ao longo do presente $\operatorname{artigo}^{1}$, a educação, em sua forma 
escolarizada, prossegue hegemonicamente apontada como a via régia de todas as salvações sociais - e, alternativamente, como o descaminho responsável por eventuais insucessos.

Neste panorama, os formadores - no caso, professores e professoras - são os mais visados pelos investimentos discursivos e institucionais daqueles que se arrogam reformadores do mundo. Formar melhor os formadores seria, alega-se, a salvação elevada ao quadrado (ou já ao cubo, ou à enésima potência...), visto que a forma inicial assumida pela formação, qualquer que seja ela, parece redundar inevitavelmente em fracasso escolar (e consequente fracasso social).

Professoras de uma universidade pública, ligadas respectivamente aos cursos de Pedagogia e de Psicologia, defrontamo-nos com uma encomenda explícita (ou com um encargo generalizado, por mais que nem sempre formulado às claras) de contribuir com essa "missão" formativa, dado que em princípio seríamos, por nossa posição hierárquica, "mestres dos mestres".

O presente escrito refere-se à maneira como temos lidado com tal encomenda ou encargo. Menos do que recusá-lo a priori, vimos buscando analisá-lo com o auxílio de alguns autores, nacionais e internacionais, Michel Foucault em especial, que consideramos como companheiros na tarefa de promover deslocamentos - quer no que tange à "escola-salvação", quer no que remete à "salvação da escola". Mediante esses deslocamentos, não repudiamos o tema da formação; porém a divisamos como uma formação outra que requer, para efetivar-se, pensamento e invenção - no caso, considerados sinônimos.

\section{Modos de vida}

Empenhamo-nos em viver entre formação e universidade. Aquilo que nos acontece em tal modo de vida é o fio que guia certos traçados existenciais relativos ao problema que nos mobiliza: o de uma formação que possa ser acatada, mas jamais entendida como salvacionista - deslocada, portanto, dos caminhos hegemônicos em que a têm situado os especialistas.

Os traçados existenciais a que nos referimos nem sempre são imediatamente visíveis, embora não estejam ocultos ou carentes de alguma interpretação sapiente. Para apreendê-los, contudo, são necessários dispositivos (FOUCAULT, 2008; DELEUZE, 2016) que façam ver e falar a constituição de uma formação perspectivada pela invenção, ou melhor, a constituição de uma política que una conhecer, fazer e viver. Tal formação, 
que é necessariamente uma política, devido a não ser dada aprioristicamente, precisa, portanto, ser cartografada (DELEUZE; GUATTARI, 2004a).

Adotando o princípio cartográfico - definível como o ato político-investigativo de partir das forças e dos processos, jamais das formas eventualmente resultantes, e sempre provisórias -, este texto procura tecer algumas das análises que temos feito em pesquisasintervenção realizadas com formação (de professores e, eventualmente, de psicólogos), bem como os estudos foucaultianos que as atravessam, realizados na Universidade do Estado do Rio de Janeiro - UERJ. O intuito, como vimos ressaltando, é conferir visibilidade e enunciação ao que temos realizado entre alunos e professores no âmbito da formação, polemizando o lugar comum do especialista, ou seja, daquele profissional ou pesquisador que assume como próprio um caráter de transmissão e que considera ter por função dotar o sujeito (formando) de determinados saberes, atitudes e capacidades dos quais ele careceria.

Contrárias a esta posição, pensamos a formação exatamente pela possibilidade de se deslocar dos lugares acostumados à "dimensão especialista" (DIAS, 2011) - aquela que diz o que o outro deve seguir e fazer; aquela que explica e possui um fim (entendido como objetivo e como término) antecipadamente dado a ser alcançado. E o que colocamos em análise são justamente as políticas que atravessam este modo específico de habitar universidade e formação. Para tanto, acompanhamos processos (PASSOS; KASTRUP; ESCÓSSIA, 2009) mediante uma ininterrupta problematização.

Quais sentidos fazemos operar quando, a cada semestre, perguntamos aos estudantes de Pedagogia e/ou Psicologia o que os move na formação? Quais são as linhas que operam a favor dos movimentos e que funcionam na produção de singularidades e diferenças? Seriam os movimentos inventivos, na formação, uma abertura para a possibilidade de diferir de si mesmo? O que chamamos efetivamente de formação quando nossa aposta é deslocar e inventar?

No presente texto, trazemos à cena alguns dispositivos que, compostos por linhas que traçamos neste entrelugar - universidade e formação -, nos forçam a pensar, já que o pensamento não é uma atividade espontânea. O que temos feito regularmente para sair (para sermos arrancados, melhor dizendo) do lugar naturalizado da formação é colocar nossa atenção no presente vivo e intenso, procurando fazer ver e falar o que nos acontece. Em termos bastante simples, porém precisos, trata-se de estabelecer (e de estar atento a) uma relação de habitar o território, de se encontrar, estudar e conversar (DIAS, 2012b). 
O ensaio, diz Michel Foucault (1994a), é uma experiência modificadora de si. Ensaiamos, pois, práticas de estar e de fazer/fazer-se nos espaços formativos, de cunho não necessariamente conceitual, teórico ou funcional, porém, tão ou mais frequentemente, ético, estético e político. Foucault estava ciente da força desse modo de fazer análise e de intervir, modo este que, para nós, dá o tom de uma aposta (metodológica?) de formação via deslocamentos:

Meu problema ou a única possibilidade de trabalho teórico que me anima seria deixar [...] o vestígio dos movimentos devido aos quais não estou mais no lugar em que estava há pouco. Donde, vamos dizer, essa perpétua necessidade [...] de fazer de certo modo o levantamento dos pontos de passagem em que cada deslocamento pode vir [...] a modificar, se não o conjunto da curva, pelo menos a maneira como podemos lê-la e podemos apreendê-la no que ela pode ter de inteligivel. Esse levantamento, por conseguinte, nunca deve ser lido como o plano de um edifício permanente. [...] Tratase, mais uma vez, de um traçado de deslocamento, isto é, não de um traçado de edifício teórico, mas do deslocamento pelo qual minhas posições teóricas não param de mudar (FOUCAULT, 2014a: 70-71) (grifos nosso).

Os traçados de Michel Foucault nos têm auxiliado a pensar/fazer formação pelo que se move/ nos move para enfrentar o presente e nele forjar transformações. Em especial, visamos a cartografar movimentos que nos desprendam dos exercícios de poder, servindo de reveladores para as transformações do sujeito - inclusive, ou primordialmente, das relações que este mantém com a verdade. Tal questão, que se distribui pelo que Foucault chama de um tríptico, atravessa todo o trabalho do filósofo, como ele nos diz em seus últimos cursos, em particular na primeira aula de $O$ governo de si e dos outros, ministrada em 5 de janeiro de 1983:

o que procurei fazer foi uma história do pensamento. E por "pensamento" queria dizer o que se poderia chamar de focos de experiência, nos quais se articulam uns sobre os outros: primeiro, as formas de um saber possivel; segundo, as matrizes normativas de comportamento para os indivíduos; e enfim os modos de existência virtuais para sujeitos possíveis. (FOUCAULT, 2010: 4).

A fim de desdobrar essa proposta, como faz o próprio Foucault ${ }^{2}$, cumpre voltar a nossa aposta metodológica para pensar a formação: a do deslocamento. Nesse intuito, o filósofo nos sugere a prática do que denomina anarqueologia (FOUCAULT, 2014a)

A anarqueologia é uma atitude teórico-prática que suspende os exercícios de poder, deles não fazendo nenhum uso. Torna-se possível, com isso, uma aproximação ao mundo social, ao modo de ser do sujeito e ao pensamento sem que eles, como é comum em outras abordagens, se vejam subrepticiamente tomados por garantidos e vistos como necessários. Nessas abordagens que Foucault almeja descartar, certos universais conhecimentos, instituições, hierarquias, classificações, modos de subjetivação etc. - 
emergem naturalizados, na forma de transcendências explicativas, em lugar de se oferecerem como contingências somente explicáveis por determinados modos, sempre singulares, de exercício do poder. Sobre o contraste entre o pequeno procedimento anarqueológico que propõe e as grandes manobras filosóficas, sempre cercadas de honrarias, Foucault assinala:

Digamos que se o grande procedimento filosófico consiste em estabelecer uma dúvida metódica que suspende todas as certezas, o pequeno procedimento lateral e na contramão que proponho a vocês consiste em fazer intervir sistematicamente não a suspensão de todas as certezas, [...] mas a não-necessidade de todo poder, qualquer que seja (FOUCAULT, 2014a: 72)

A anarqueologia foucaultiana problematiza, portanto, os universais: embora inteligíveis, as práticas de qualquer espécie - as de formação nos interessam em especial - estão afetadas de uma contingência radical; ou seja, de uma fragilidade, de uma não necessidade, de um caráter de matéria bruta sempre passível de transformação. Trata-se, nessa perspectiva anarqueológica, de evitar partir de quaisquer posições naturalizadas para dizer, por exemplo: eis o que é a formação; eis o que é a natureza da formação; eis o que é capaz de libertar a formação. A tais posições, tão fortemente associadas que podem ser vistas como uma série ("categoria universal-posição humanista-análise ideológica"), Foucault contrapõe outra série, que ele defende enfaticamente e chama de "série recusa dos universais-posição anti-humanista-análise tecnológica dos mecanismos de poder" (FOUCAULT, 2014a:74).

Com o auxílio de tais procedimentos metodológicos - contra-metodológicos ${ }^{3}$, melhor dizendo -, que, na linguagem da Análise Institucional francesa, diríamos que privilegiam a análise de nossas implicações com as instituições em jogo (LOURAU, 1993; RODRIGUES, no prelo), retornaremos mais detidamente, a partir de agora, à noção de deslocamento. Nessa direção, usaremos em primeiro lugar as linhas tecidas no dispositivo aula - especificamente, tomaremos uma daquelas que integram o curso $A$ Hermenêutica do Sujeito (FOUCAULT, 2004a), o que nos ajudará a colocar em análise a tessitura da anarqueologia como atitude prática para pensar/fazer uma formação que se desvincule de pedagogias capacitadoras, aliando-se, alternativamente, à atividade éticopolítica.

Em seguida, usaremos linhas do dispositivo delimitado por meio de entrevistas (FOUCAULT, 1994b; 2014b; 2004b) e alguns escritos de intercessores de Foucault (DELEUZE, 2003; 2016; CHEVALLIER, 2015; GROS, 2015) para indagar se a 
formação perspectivada pela invenção pode ser uma formação outra, uma formação problematizadora.

Em um terceiro e último momento, o texto dará a ver algumas estratégias singulares de formar professores, as quais privilegiam práticas éticas e políticas que envolvem exercícios regulares e trabalhos dotados de continuidade, porém sem efeitos de coerção. Pois a formação, aqui, não procede nem de uma lei nem de obrigações, mas se constitui, imanente, facultativa e perspectivada, por encontros e conversas. Esses ganham, nesta parte do artigo, uma polifonia singular, quando escritas de diários de professoras de escolas básicas parceiras das pesquisas se inserem no trabalho.

\section{Dispositivo 1: a aula}

Organizar este escrito mediante três dispositivos que procuram tornar visível o que nos move fala de um modo de formação atento às tessituras micropolíticas que emergem de certos encontros, bastante singulares, consigo, com o outro, com outros. Neste sentido, começamos pela aula ministrada por Foucault em 10 de fevereiro de 1982 (FOUCAULT, 2004a). Na primeira hora, ele se propõe a explicitar a dupla desvinculação do cuidado de si - tanto em relação à pedagogia quanto em relação à atividade política ocorrida no período helenístico-romano.

Doravante, o cuidado de si deixa de ser mero preceito complementar ou substitutivo da pedagogia preexistente, na forma de relação singular entre mestre e discípulo que se impõe ao jovem no momento em que vai entrar na vida adulta - preceito bem situado no tempo e restrito àqueles que, por seu estatuto, detêm a possibilidade de governar os demais -, para ser visto como injunção válida para todo o desenrolar da existência e, em certa medida, para todos, constituindo uma espécie de cultura de si.

O cuidado de si é, a partir de então, coextensivo à vida: vale para o desenrolar da existência inteira, em lugar de constituir mero artefato pedagógico localizado num ponto específico do tempo. A desvinculação quanto à pedagogia expressa-se, além disso, no entrelaçamento da prática de si com "toda uma rede de relações sociais diversas" (FOUCAULT, 2004a: 254) que lhe podem servir de suporte - organizações escolares, ação de conselheiros privados, relações familiares, de proteção, de amizade etc. -, em acréscimo às relações estritas de mestria.

Já a desvinculação quanto à atividade política afasta-se do caráter, digamos, instrumental que até certo momento - figurado pelo diálogo platônico Alcibíades - 
cercava o cuidado de si. Se, antes, estar atento a si tinha como objetivo ocupar-se bem com os outros e com a cidade, agora esse cuidado mostra-se autofinalizado: "é preciso ocupar-se consigo para si mesmo, de maneira que a relação com os outros seja deduzida, implicada na relação que se estabelece de si para consigo" (FOUCAULT, 2004a: 254).

Sintetizando as duas desvinculações, emerge a imagem da volta para si mesmo: “é preciso, durante toda a vida, voltar a atenção, os olhos, o espírito, o ser por inteiro enfim, na direção de nós mesmos" (FOUCAULT, 2004a:254). Trata-se, por conseguinte, de uma conversão, de fazer a volta em direção a si mesmo, embora se deva ressaltar que, mais do que um conceito ou uma noção estrita, essa conversão (a si) é uma espécie de “esquema prático". Para Foucault (2004a: 256), isso em nada a desvaloriza: dentre as diversas "tecnologias do eu" conhecidas pelo Ocidente, ela foi, e é ainda, uma das mais importantes.

Neste ponto, a aula convida a que nos voltemos para o presente. Porque Foucault, sem deixar de mencionar a importância religiosa, notadamente cristã, da conversão, adverte-nos de seu relevo filosófico, moral e, em particular, político. Quanto ao último aspecto, assim se expressa: "Parece-me [...] que não se pode compreender o que foi, ao longo do século XIX, a prática revolucionária, o que foi o indivíduo revolucionário e o que foi para ele a experiência da revolução, se não se levar em conta a noção, o esquema fundamental da conversão à revolução". (FOUCAULT, 2004a: 256)

Em tempos, os nossos, em que tanto se alegam decepções com a política revolucionária, a proposta de Foucault, que conclama a analisar de que forma uma tecnologia de si tão antiga como a conversão se vinculou a um domínio tão novo como era, no século XIX, a política como escolha e prática revolucionária, soa bastante provocadora, porque capaz de nos advertir quanto ao caráter inesgotável, e com frequência inesperado, das transformações nos modos de subjetivação. No entanto, o filósofo igualmente se reúne, conquanto de forma matizada, a nossos receios atuais, acrescentando:

Seria preciso examinar também de que modo esta noção de conversão foi pouco a pouco sendo validada - depois absorvida, depois enxugada e enfim anulada - pela própria existência de um partido revolucionário. E de que modo passamos do pertencimento à revolução pelo esquema de conversão ao pertencimento à revolução pela adesão a um partido. Sabemos que hoje em dia [...] só nos convertemos à renúncia da revolução. Os grandes convertidos de hoje são os que não creem mais na revolução. (FOUCAULT, 2004a: 257) 
Ao concluir este segmento da aula com a frase "haveria aí toda uma história a ser feita”, Foucault (2004a: 257) nos desafia mediante uma sutil ambiguidade: porque essa história a ser feita não é somente aquela da reconstrução de acontecimentos pretéritos, e aponta também à importância da conversão na elaboração, presente e futura, de práticas (revolucionárias?) de resistência ao poder político que não se vejam anuladas pela adesão a instâncias cooptadoras e burocratizantes. O problema atual da formação formação de professores, de trabalhadores, estudantil etc. - está aí implicado, certamente.

Retornando ao momento helenístico-romano, Foucault diferencia o tema da conversão então vigente da epistrophé platônica, comandada por uma oposição fundamental entre este mundo - o das aparências - e o outro - o das essências. $\mathrm{O}$ tipo de conversão que encontramos na prática de si helenístico-romana não se move neste eixo, pois o retorno a si deve fazer-se na imanência do mundo, por mais que ainda exista uma oposição considerada essencial. Tal oposição, no entanto, não consiste em uma ascensão a outro mundo, mas em um deslocamento "do que não depende de nós ao que depende de nós" (FOUCAULT, 2004a: 258).

Cumpre uma vez mais ressaltar que esse deslocamento, essa liberação a ser obtida pela conversão a si, efetua-se no interior de um eixo de imanência: remete a tudo aquilo que não dominamos, a fim de alcançar aquilo que podemos dominar. Sendo assim, e ainda em contraste com a epistrophé platônica, não se trata de uma liberação da alma em relação ao corpo, do qual a primeira seria prisioneira, mas de uma adequação de si para consigo. Por fim, outra diferença está no papel desempenhado pelo conhecimento, o qual não mais é considerado tão decisivo: "bem mais do que o conhecimento, será o exercício, a prática, o treinamento, a áskesis, que constituirá o elemento essencial" (FOUCAULT, 2004a: 259).

Encerrando a primeira hora da aula, Foucault distingue a conversão helenísticoromana daquela que encontraremos na cultura cristã de tipo monástico. Não o seguiremos nesse detalhamento, limitando-nos a enfatizar que a conversão a si, no primeiro caso, não implica, como no último, uma ruptura - na cultura cristã dos séculos III e IV d.c., "o eu que se converte é um eu que renunciou a si mesmo". (FOUCAULT, 2004a: 260). Existe, sim, uma ruptura na conversão helenístico-romana, mas ela se dá quanto a tudo aquilo que cerca o eu, a fim de que este não mais seja escravo ou dependente. Há "ruptura do eu relativamente a tudo o mais", pois, como afirma Foucault citando o estoico Sêneca, "a filosofia faz com que o sujeito gire em torno de si mesmo, isto é, faz com que ele execute 
o gesto pelo qual, tradicional e juridicamente, o mestre liberta seu escravo"(FOUCAULT, 2004a: 261).

Voltar-se sobre si mesmo, girar sobre si mesmo, constituem "relações de si para consigo que podem ter a forma de atos. Por exemplo: protege-se, defende-se, arma-se, equipa-se o eu" (FOUCAULT, 2004a: 263). Mas o que significa desviar o olhar das coisas do mundo para conduzi-lo a si? - questão considerada complexa por Michel Foucault, tanto que será desenvolvida na segunda hora da aula. Ela se liga, vale lembrar, a duas outras indagações que ressoam no cerne do trabalho do filósofo: "como se estabelece, como se fixa e se define a relação entre o dizer-verdadeiro (a veridicção) e a prática do sujeito? Como o dizer-verdadeiro e o governar (a si mesmo e aos outros) se vinculam e se articulam um ao outro?" (FOUCAULT, 2004a: 281).

Na segunda hora, Foucault se detém na questão da filosofia antiga, acentuando a perspectiva assumida a esse respeito por Pierre Hadot (2014: 214), para quem ela é "um convite para cada homem transformar a si mesmo [...], conversão, transformação da maneira de ser e da maneira de viver". Nesse sentido, indaga Foucault (2004a): poderíamos considerar o caráter assumido pelas escolas filosóficas do período helenístico-romano, que propõem um desvio do olhar das coisas do mundo para dirigi-lo a si, como uma espécie de prenúncio da importância maior dos saberes sobre o homem quando comparados aos saberes sobre o mundo e a natureza? Mais uma vez se percebe a importância das questões levantadas na aula em pauta para a abordagem atual do tema da formação, quando se discute ininterruptamente, entre os especialistas, que conhecimentos seriam indispensáveis a um "professor bem formado".

Sócrates já evocara tal tema, perguntando, no Fedro, se deveríamos escolher o conhecimento das árvores ou o dos homens e optando pela segunda alternativa. Nas análises que desenvolve sobre esse problema, Foucault (2004a) opta por focalizar o modo como ele é colocado nos cínicos e nos epicuristas ${ }^{4}$.

No que tange aos cínicos, recorre a um texto de Demetrius, citado por Sêneca, onde o primeiro, tomando por modelo a imagem do atleta, efetua uma espécie de triagem quanto ao que seria efetivamente necessário conhecer para sair-se bem em tal atividade poucos movimentos, por sinal. Com isso, Foucault vê emergir o que poderia constituir um "critério de utilidade", pois se tem "a impressão de uma divisão no conteúdo mesmo dos conhecimentos, entre conhecimentos inúteis, que poderiam ser os do mundo exterior, etc, e conhecimentos úteis, que tangenciam diretamente a existência humana" (FOUCAULT, 2004a:284). Apreciemos com mais vagar, porém, a maneira como 
Demetrius distingue o que merece e o que não merece ser conhecido, a fim de verificar se a diferença por ele estabelecida aponta efetivamente ao conteúdo do conhecimento.

O texto do filósofo cínico é composto por duas listas que remetem, respectivamente, ao que é inútil e ao que é útil conhecer. No primeiro caso, diz Foucault (2004a: 285), "temos a causa dos maremotos, a causa do ritmo dos sete anos que cadenciariam a vida humana, a causa das ilusões de ótica, o motivo de haver gêmeos e o paradoxo de duas existências diferentes e nascidas sob o mesmo signo, etc."

Apreciando essa série, Foucault não vê os conhecimentos nela incluídos como relativos a coisas pertencentes a um mundo afastado e que, nesse sentido, não tangenciariam a existência humana. Pelo contrário. Consequentemente, modifica sua hipótese inicial quanto àquilo que constituiria o caráter comum do que é julgado inútil por Demetrius:

O traço comum e que as tornará inúteis é que se trata [...] de conhecimentos pelas causas. [...] E, para Demetrius, se a natureza tivesse considerado que essas causas [...] poderiam ser importantes para a existência e para o conhecimento humanos, ela as teria mostrado [...]. Estão ocultas porque é inútil conhecê-las [...] não porque proibido, mas porque [...], ao conhecê-las não obteremos mais do que algo suplementar ${ }^{5},[. .$.$] , a$ título de distração e para sentir um prazer que reside, precisa e unicamente na própria descoberta [...]. Prazer de cultura, por consequência, prazer suplementar, prazer inútil e ornamental. (FOUCAULT, 2004a: 286-287)

O que seria útil conhecer, então, para Demetrius? Assim é sintetizada a lista apresentada pelo filósofo cínico: “Que há pouco a temer dos homens, nada a temer dos deuses, que a morte não produz nenhum mal, que é fácil achar o caminho da virtude, que é preciso considerar-se como um ser social nascido para a comunidade. Enfim, saber que o mundo é um habitat comum, onde todos os homens estão reunidos para justamente constituir esta comunidade" (FOUCAULT, 2004a: 287)

Essa série em nada se aproxima do que a espiritualidade cristã virá a chamar de "segredos da consciência" (arcana conscientiae). Tampouco encaminha à necessidade de um exame de consciência para ser estabelecida. Não há inventário de uma interioridade, de um mundo interior de desejos, paixões, enfermidades. Inexiste teoria da alma ou da natureza humana. No plano do conteúdo, segue-se falando dos deuses, do mundo, dos outros homens, e não do próprio indivíduo. Não se reivindica desviar o olhar da natureza para voltá-lo quer para si mesmo, quer para a consciência, quer para as profundezas da alma.

Se é assim, ou melhor, se se trata, "somente e sempre, do mundo, [...], somente e sempre, dos outros, [...] somente e sempre, do que nos cerca" (FOUCAULT, 2004a: 287- 
288), o que define a utilidade desses conhecimentos, separando-os dos inúteis? Enquanto estes últimos são, como vimos, uma certa modalidade de saber - "pelas causas" -, os primeiros seguiriam um modo de saber que Foucault (2004a:288) propõe chamar de "relacional”, pois "o que há que se ter em conta quando consideramos os deuses, os outros homens, o kósmos, o mundo etc. é a relação entre, por um lado, os deuses, os homens, o mundo, as coisas do mundo, e, por outro, nós" - termo recorrente e constante de todas estas relações, o último, daí o havermos ressaltado em itálico.

Além disso, esse saber ou conhecimento relacional tem a propriedade de ser imediatamente transcriptível em prescrições, e é assim, inclusive, que ele aparece no texto de Demetrius. No dizer de Foucault (2004a: 288-289), esses conhecimentos constituem “constatações prescritivas”, isto é, neles “o que há a conhecer, ou melhor, a maneira como se há de conhecer é tal que o que é dado como verdade seja lido, de saída e imediatamente, como preceito".

Por fim, uma vez que se tenham adquirido esses conhecimentos relacionais, o modo de ser do sujeito se acha transformado, pois, ao adquiri-los, nos tornamos melhores, o que não ocorre no caso do "ornamento da cultura". A hipótese de que o conteúdo do conhecimento seja o elemento definidor da utilidade é, assim, definitivamente descartada.

Os conhecimentos [...] inúteis, que são rejeitados por Demetrius, [...], não se definem pelo conteúdo. Definem-se por um modo de conhecimento causal, com dupla propriedade, ou melhor, com dupla falta [...]: são conhecimentos que não podem transformar-se em prescrições, que não têm pertinência prescritiva; em segundo lugar, que, quando os possuímos, não têm efeito sobre o modo de ser do sujeito. Em contrapartida, será validado um modo de conhecimento que, considerando todas as coisas do mundo [...] relativamente a nós, de pronto poderemos transcrever em prescrições, e elas modificarão o que somos, modificarão o estado do sujeito que as conhece (FOUCAULT, 2004a: 289).

A ética da verdade das demais escolas filosóficas passa pela mesma linha divisória: possuírem, ou não, os conhecimentos em pauta efeitos sobre a maneira de agir (ethos) do sujeito. Com base em uma série de expressões de Plutarco, Foucault (2004a: 290) opta por dizer determinante o caráter “etopoético", ou não, do saber. E, sem demora, passa à leitura de alguns textos epicuristas, nos quais identifica uma noção ligada ao modo de funcionamento etopoético, a physiología (fisiologia) - "modalidade do saber da natureza enquanto filosoficamente pertinente para a prática de si” (FOUCAULT, 2004a: 291).

Seguindo-se a essa breve definição, Foucault prefere acompanhar Epicuro quando este, nas Sentenças Vaticanas, privilegia de início especificar o que a fisiologia não é: “O 
estudo da natureza (physiologia) não forma fanfarrões nem artistas do verbo, nem pessoas que ostentam uma cultura julgada inviável para as massas, mas homens altivos e independentes, que se orgulham de seus próprios bens, não dos que advêm das circunstâncias" (citado por FOUCAULT, 2004a: 291).

Tudo o que a physiologia não é caracteriza a paideía ${ }^{6}$, a respeito da qual, diferentemente da maior parte de seus contemporâneos, Epicuro é extremamente crítico. Na paideía, trata-se de uma espécie de saber de jactância, cultura elaborada por "artistas do verbo", melhor dizendo, artistas da palavra entendida como ruído (e não como lógos), cuja única meta é "fazer-se admirar pelas massas" (FOUCAULT, 2004a: 292). Em oposição à paideía, o que faz a physiologia? Ela prepara, ela equipa (paraskeuázei) - para retomar as palavras de Epicuro - homens altivos que não temem e se dotam da coragem que lhes permite afrontar as crenças, os perigos da vida e as autoridades. Além do mais, esses homens são independentes (autarkê̂s), de nada necessitam além deles próprios e, ao reconhecerem a partilha entre o que depende e o que não depende deles, estabelecem domínio total, absoluto e sem limites quanto ao primeiro aspecto.

Para quem se interessa pelo tema e prática da formação na contemporaneidade, como não ver na distinção estabelecida por Epicuro entre physiologia e paideía, embora com o cuidado de evitar anacronismos simplificadores, um equipamento (paraskeué) extremamente útil - no sentido que este adjetivo assume no período helenístico-romano - para avaliar o que efetivamente importa? A paraskeué, nos diz Foucault (2004a: 293), é “a equipagem, a preparação do sujeito e da alma pela qual o sujeito e a alma estarão armados como convém, de maneira necessária e suficiente, para todas as circunstâncias possíveis da vida com que viermos a nos deparar, [...] o que permitirá resistir a todos os movimentos que poderão advir do mundo exterior”. O resto, concluímos nós, é ornamento, jactância, mero ruído elitista.

No momento em que o professor Foucault se dá conta de que a aula de 10 de fevereiro chega ao fim, afirma que ainda gostaria de se deter em alguns aspectos importantes. Refere-se novamente a Epicuro quando este, em outra Sentença Vaticana, usa a expressão "liberdade de palavra" (citado por FOUCAULT, 2004a: 294). A palavra grega correspondente é parrhesía, que, neste primeiro (ou um dos primeiros) enfoque(s) por parte de Foucault, consiste em um termo técnico. Nessa linha, a técnica da parresía

permite ao mestre utilizar como convém, nas coisas verdadeiras que ele conhece, o que é útil, o que é eficaz para o trabalho de transformação de seu discípulo. [...] É aquela liberdade de jogo, se quisermos, que faz com que, no campo dos conhecimentos verdadeiros, possamos utilizar aquele que é 
pertinente para a transformação, a modificação, a melhora do sujeito. (FOUCAULT, 2004a: 295)

A parrhesia será objeto de estudo dos dois cursos seguintes de Foucault, $O$ Governo de si e dos outros e A coragem da verdade. Neles surgirão, entre outros aspectos: diferenças entre a parresía política e a parresía filosófica; contrastes e correlações entre as modalidades parresiástica, profética, sábia e técnico-pedagógica de relação do sujeito com a verdade; ênfase na parresía como franco falar ou dizer verdadeiro que implica a coragem para enfrentar riscos ou perigos; incursões na vida filosófica como vida outra, vida verdadeira, vida militante, através do estudo minucioso do cinismo antigo etc.

Em todos esses pontos, a parresía se manifesta pela palavra e pelo gesto verdadeiros que afetam o sujeito, e não através de um sujeito que se torna objeto de um discurso verdadeiro. A temática é demasiado extensa e nela não nos deteremos, mas reconhecemos que lança novas pistas para pensar a diferença entre conhecimento ornamental e relacional, causal e etopoético, inútil e útil, através de caminhos bem distintos dos ligados a conteúdos ou objetos do saber.

Mediante tais pistas, efetuam-se novos deslocamentos para reunir logos e ethos, conhecimento e cuidado, o plano do enunciado, que está nos dizeres, e o plano do sensível, que está nos olhares. Em outras palavras, trata-se de fazer a verdade que se diz, porque, para Foucault, a verdade é, "no sentido mais justo e literal da expressão, uma razão de viver, ou seja, um lógos atualizado na existência, e que a anima, intensifica e prova: verifica-a" (GROS, 2004: 641)

\section{Dispositivo 2: formação perspectivada pela invenção}

Deslocamento, esforço e movimento nos têm acompanhado na trajetória desta discussão que liga universidade, formação e estudos foucaultianos, no propósito de afirmar uma formação intensiva que não esteja associada a qualquer sistema autoritário, seja jurídico, seja disciplinar. A formação a que nos referimos não procede de leis e/ou normas constituintes: está inscrita na própria vida dos estudantes e dos professores.

O que seria, mais exatamente, pensar e fazer formação perspectivada pela invenção? Que sentidos é possível expressar quando tomamos a invenção como modo de estar/fazer na universidade? Como pensar um modo desacomodado de estar na universidade e na formação? Quando optamos por caminhar por meio de dispositivos, colocamos em análise as linhas da tessitura da experiência. 
Em uma entrevista a Ducio Trombadori, datada de 1978, Foucault (1994b: 43) aborda justamente a questão da experiência. Diz ele, então, que seus livros foram provocados por experiências; que os próprios livros, aliás, são experiências; que uma experiência é aquilo “de que se sai transformado". Para o filósofo, o problema principal não reside em trazer à luz "a significação da experiência quotidiana para reencontrar, no que sou, o sujeito fundador"; ao contrário, a experiência tem por função "arrancar o sujeito de si mesmo, fazer com que ele não seja mais ele mesmo", em um empreendimento de "des-subjetivação".

Conforme proposto no início deste artigo, a entrevista acima mencionada, algumas outras presentes nos Ditos e Escritos de Michel Foucault e textos de intercessores tomam os fios soltos deste momento, deles fazendo mais um dispositivo, para indagar em que medida conseguimos manter vivo, na formação, um campo problemático - campo este que vemos como princípio, no sentido de base e de começo, para uma formação inventiva de professores (DIAS, 2012a).

Levamos a sério, nesse sentido, o que Deleuze (2016: 363-365) nos diz acerca de duas consequências do pensar por dispositivos: o "repúdio dos universais" e a "mudança de orientação, que se desvia do Eterno para apreender o novo". "Pertencemos a dispositivos e neles agimos", afirma em seguida, pois o que emerge do encontro com o que ainda não está delineado é a diferença. Por isso, não é possível antecipar uma experiência, apenas estar atento aos acontecimentos e singularidades.

Nessa linha de pensamento, Deleuze (2016: 367-368) acentua que para apreender a obra de Foucault não é possível deixar de fora suas entrevistas, pois enquanto nos livros ele nos fala sobretudo de "linhas de sedimentação" ou "estratificação", nas entrevistas contemporâneas a cada um desses livros traça "linhas de atualização" ou "criatividade", diagnósticos do presente que nos empurram "para um porvir, para um devir". E é junto a essas últimas linhas que insistimos: mais importante do que pensar é o que nos força a pensar - frase também de Deleuze (2003), afirmativa da potência da problematização. Com isso, de novo justificamos a presença, neste ponto do presente escrito, de passagens de entrevistas concedidas por Foucault, pois estas procuram dar a ver os movimentos de uma problematização.

Em entrevista a Dreyfus e Rabinow, datada de 1983, Foucault busca esclarecer o que vem a ser seu retorno aos gregos em meio ao trabalho sobre a história da sexualidade. Ele insiste, então, na categoria de problematização: 
Eu não procuro uma solução de reserva; não se encontra a solução de um problema na solução de outro problema apresentado em outra época por pessoas diferentes. O que quero fazer não é uma história das soluções. Penso que o trabalho que se deve fazer é um trabalho de problematização e de perpétua reproblematização. O que bloqueia o pensamento é admitir implícita ou explicitamente uma forma de problematização e buscar uma solução que possa substituir-se àquela que se aceita. Ora, se o trabalho do pensamento tem um sentido - diferente daquele que consiste em reformar as instituições e os códigos -,é retomar na raiz a maneira como os homens problematizam seu comportamento (sua atividade sexual, sua prática punitiva, sua atitude quanto à loucura etc.) (FOUCAULT, 2014b: 217).

Em seguida, de uma forma que para alguns soa surpreendente, quase de modo otimista, Foucault ressalta o irrecusável valor do trabalho do pensamento, desde que não o essencializemos:

Acontece que as pessoas se esforçam por essa reproblematização como um "antirreformismo" repousando em um pessimismo do gênero "nada mudará". É completamente o contrário. É o apelo ao princípio de que o homem é um ser pensante, até em suas práticas mais mudas, e que o pensamento não é o que nos faz crer no que pensamos nem admitir o que nós fazemos; mas o que nos faz problematizar até o que nós somos nós mesmos. O trabalho do pensamento não é denunciar o mal que habitaria secretamente em tudo o que existe, mas pressentir o perigo que ameaça em tudo o que é habitual e tornar problemático tudo o que é sólido (FOUCAULT, 2014b: 217).

A resposta do filósofo francês a seus entrevistadores estadunidenses nos ajuda a manter de pé o princípio de uma formação inventiva de professores: problematizar. Nessa direção, seguimos com mais uma entrevista, de 1984, ano de sua morte, em que Foucault estabelece distinções entre polêmica, política e problematizações. No decorrer da mesma, indaga Rabinow: “o senhor falou antes de uma 'história das problemáticas'. O que isto quer dizer precisamente?". A resposta de Foucault nos mostra a fina camada que diferencia o trabalho do pensamento: na problematização, não se trata de um ajuste de representações, mas de um movimento de separação. Vejamos dois trechos desta longa resposta:

o que distingue o pensamento é que ele é totalmente diferente do conjunto das representações implicadas em um comportamento; ele também é completamente diferente do campo das atitudes que podem determiná-lo. O pensamento não é o que se presentifica em uma conduta e lhe dá um sentido; é, sobretudo, aquilo que permite tomar uma distância em relação a essa maneira de fazer ou de reagir, e tomá-la como objeto de pensamento e interrogá-la sobre seu sentido, suas condições e seus fins. $O$ pensamento é liberdade em relação àquilo que se faz, o movimento pelo qual dele nos separamos, constituímo-lo como objeto e pensamo-lo como problema (FOUCAULT, 2004b: 231-232).

[...] o trabalho de uma história do pensamento seria encontrar na origem dessas diversas soluções a forma geral de problematização que as tornou possíveis - até em sua própria oposição; ou, ainda, o que tornou possíveis as transformações das dificuldades e obstáculos de uma prática em um problema geral para o qual são 
propostas diversas soluções práticas. É a problematização que corresponde a essas dificuldades, mas fazendo delas uma coisa totalmente diferente do que simplesmente traduzi-las ou manifestá-las; ela elabora para suas propostas as condições nas quais possíveis respostas podem ser dadas; define os elementos que constituirão aquilo que as diferentes soluções se esforçam para responder. Essa elaboração de um dado em questão, essa transformação de um conjunto de complicações e dificuldades em problemas para os quais as diversas soluções tentarão trazer uma resposta é o que constitui o ponto de problematização e o trabalho específico do pensamento (FOUCAULT, 2004b: 233).

Foucault torce o tradicional uso da noção de problema - um obstáculo que se apresenta fora do pensamento, entendido como uma ciência já constituída - , fazendo dela um efeito do próprio pensamento. Como nos diz Chevallier (2015, p. 299), “é o pensamento que dá a si mesmo um problema. [...] A problematização é uma atividade em que se inventam novas maneiras de pensar". Uma problematização, para Michel Foucault, acrescenta Chevallier (2015: 308), constitui “a maneira na qual o pensamento se projeta adiante sob uma forma interrogativa, sem poder de modo algum antecipar o que advirá dela e das respostas que a história reterá. Ela é, então, da ordem da novidade". Retomando uma ascese, um trabalho de si sobre o pensamento, o que Foucault propõe com a problematização é um exercício de resistência - tão necessário à formação de professores -, pensado como um exercício crítico da liberdade. Na formação de professores, esse exercício pode, talvez, ser perspectivado pela invenção, pois, ao problematizar, inquietamos as certezas e adotamos uma atitude de recuo crítico quanto às evidências sociais (GROS, 2015) e suas formas históricas de problematização. Com isso, desdobramos discursos e práticas, bem como elementos de uma relação consigo a partir da qual o sujeito pode construir uma experiência de si que ousa pensar e fazer uma formação outra.

\section{Dispositivo 3: encontros e conversas}

Com as linhas deste terceiro dispositivo, como anteriormente apontado, a aposta é a de dar a ver algumas estratégias singulares de formar professores ${ }^{7}$, as quais privilegiam práticas éticas e políticas que envolvem exercícios regulares e trabalhos dotados de continuidade, porém sem efeitos de coerção. 


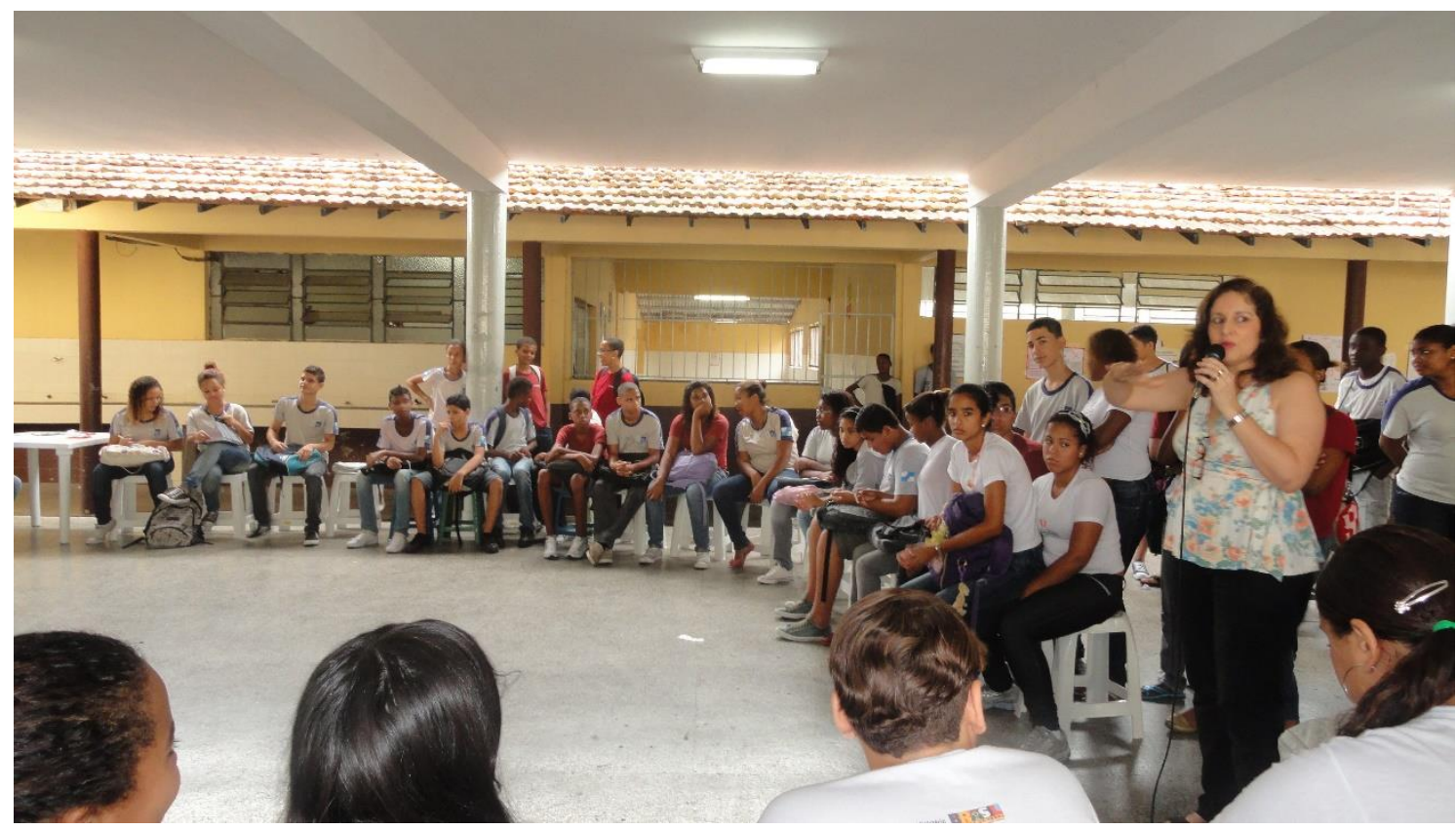

Roda de conversa no pátio do Colégio Estadual Conselheiro Macedo Soares

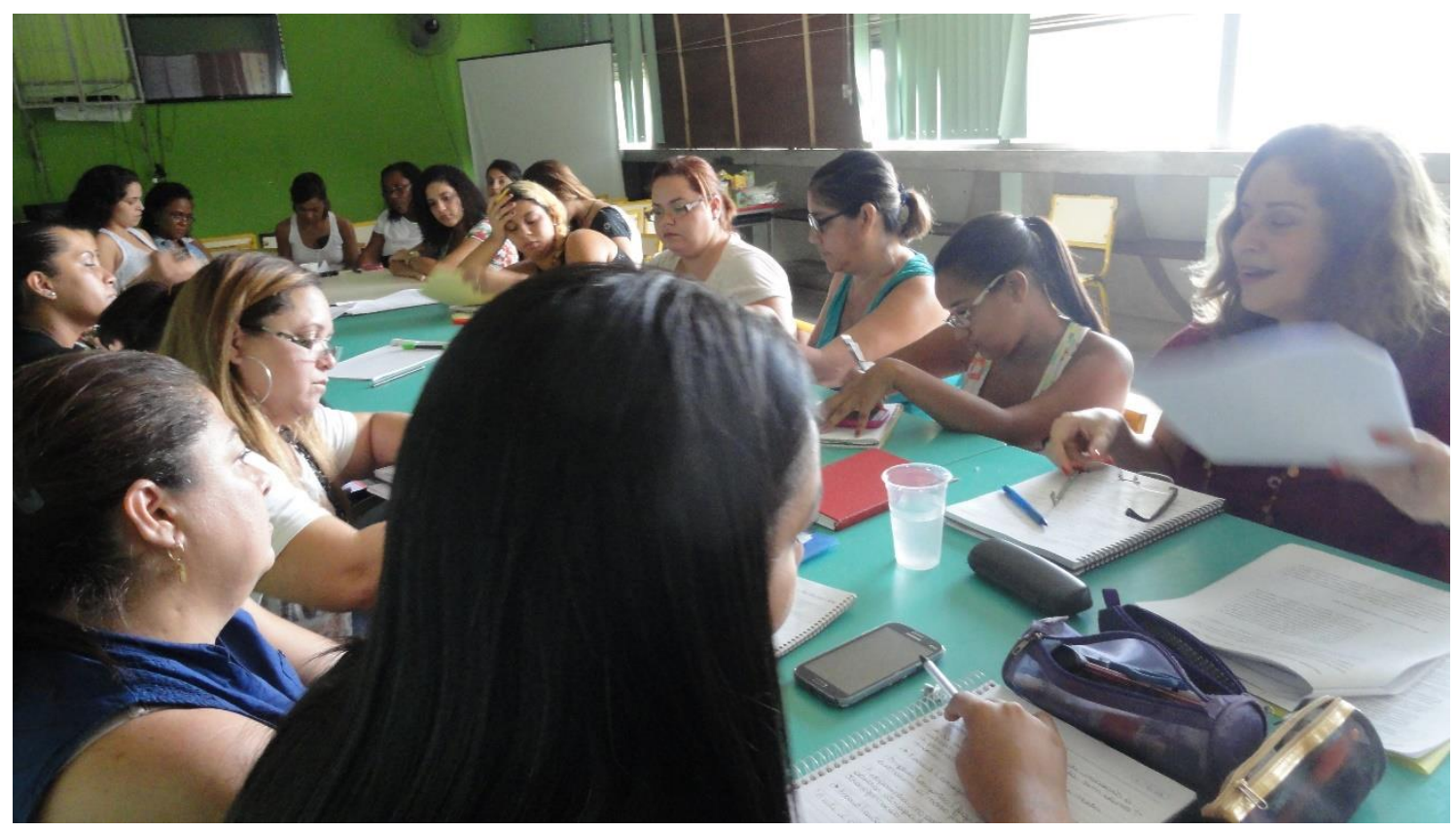

Grupo de estudos no CIEP Municipalizado 411

Quando falamos em estratégias, levamos a sério o que Michel Foucault (2008: 255) aponta a respeito: "para que uma determinada relação de forças possa não somente se manter mas se acentuar, se estabilizar e ganhar terreno, é necessário que haja uma manobra". Assim pensada, nossa estratégia de ação habita os territórios de formação 
problematizando suas leis e normas identitárias, para deixar passar as forças imanentes, facultativas e perspectivadas, pela via de encontros e conversas. Daí porque, neste artigo, recorremos a algumas escritas de diário de campo de professoras de escolas básica parceiras, apresentadas mais adiante.

O encontro entre escola básica e universidade se efetiva por meio de uma pesquisa que agencia filosofia da diferença (DELEUZE; GUATTARI, 2004), análise institucional (LOURAU, 1993), políticas de cognição (KASTRUP, 1999), pesquisa-intervenção (ROCHA, 2012) e formação inventiva de professores (DIAS, 2012b). Não se trata de um encontro marcado por conversas ligeiras ou encontros fortuitos para atender a uma necessidade imposta pelos cursos de formação de professores, tampouco de uma investigação sobre a escola básica, mas de uma pesquisa-intervenção com a escola. Uma pesquisa que aproveita as brechas entre a macro e micropolítica e entra no território escolar com a perspectiva de analisar e de intervir sobre/com o que acontece entre estudantes e professores da universidade e da escola básica, atuando de forma coletiva. Com isso, tal pesquisa vem abrir não só outras possibilidades de encontro, mas olhares outros quanto a conhecimentos e experiências do fazer pedagógico.

Avaliamos que análises e pesquisas instaladas no campo da representação, que separam sujeito e objeto, buscando a objetividade e a neutralidade científica, o diagnóstico e a solução dos problemas já dados da escola, além de repetitivas em suas proposições, não dão conta da complexidade e dinamismo da instituição educativa. Já a pesquisa-intervenção, conforme a concebe Rocha (2012), intensifica a ruptura com modos tradicionais de investigar, além de ampliar as bases teórico-metodológicas das pesquisas participativas. Surge, portanto, como proposta de atuação transformadora nas políticas, visto que propõe uma intervenção de ordem micropolítica. 


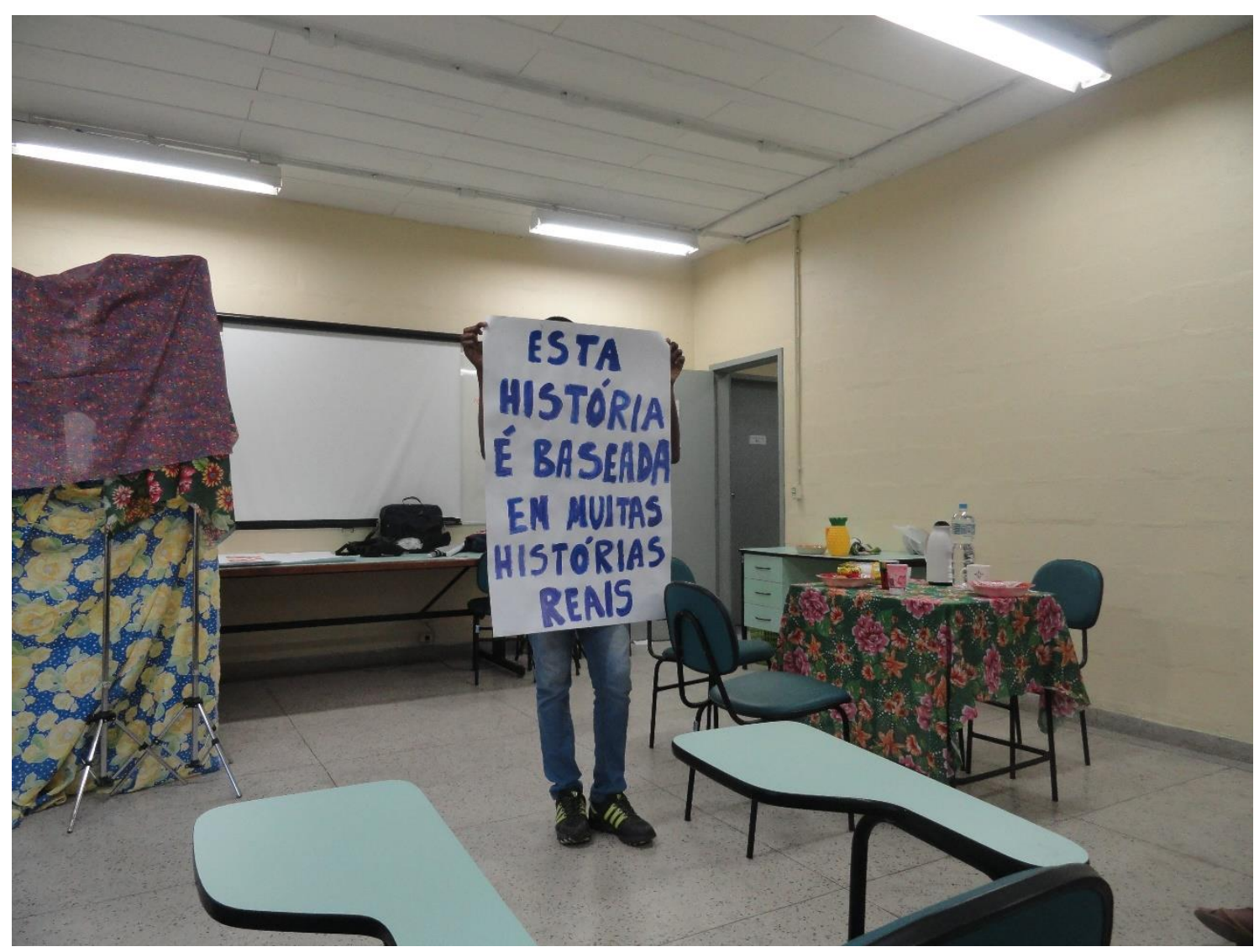

Esquete apresentada pelo Coletivo Arte Ambiente e Alteridade do CIEP Municipalizado 411 no VI Encontro e Conversas sobre formação inventiva de professores, que aconteceu na FFP com a presença de estudantes das escolas parceiras

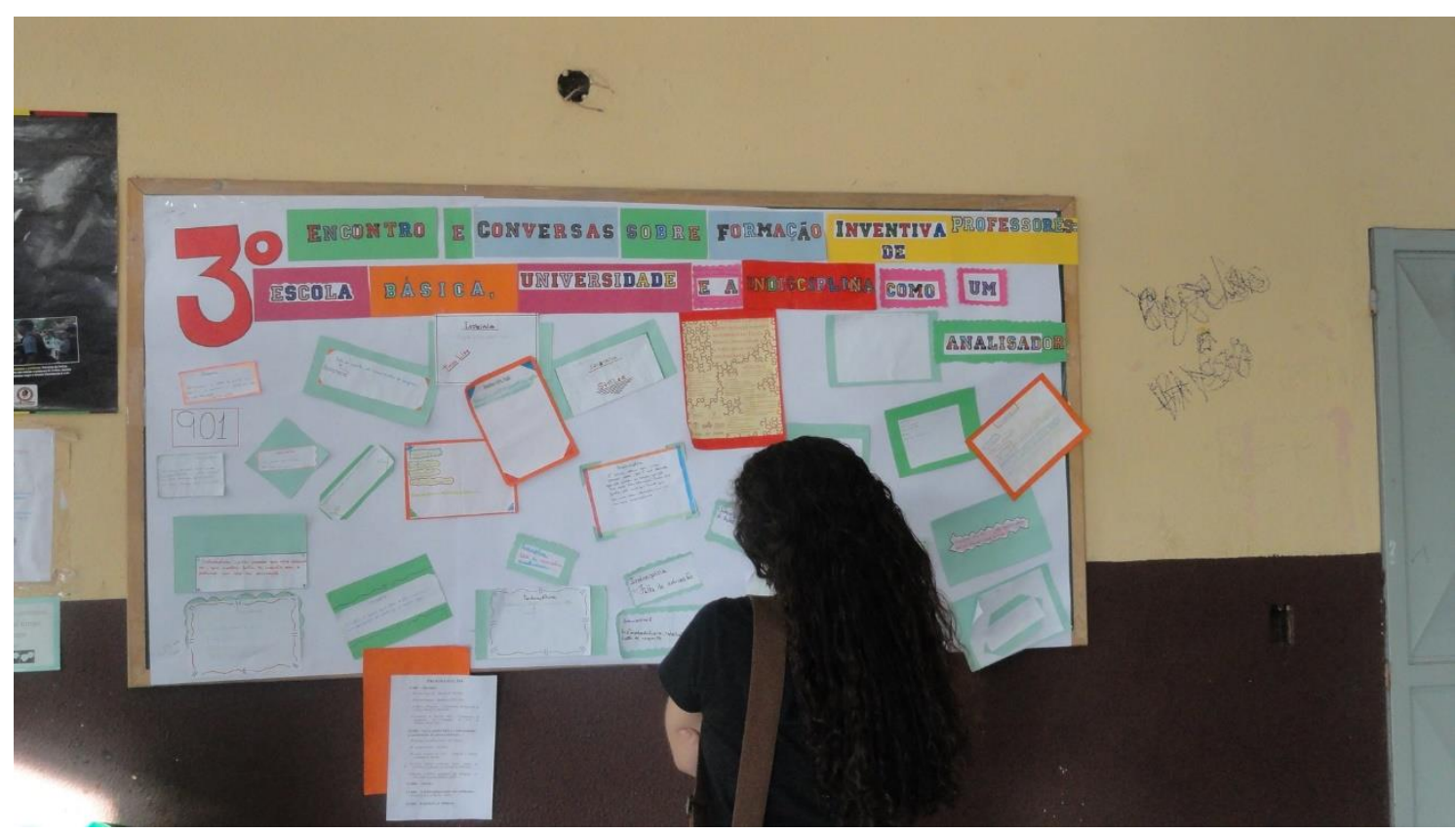

Mural do III Encontro e Conversas sobre formação inventiva de professores que aconteceu do Colégio Estadual Conselheiro Macedo Soares, para comemorar os 100 anos de existência da escola. 
Nesta perspectiva, é preciso habitar o território da escola, abrir-se para as experiências, os movimentos, as imprevisibilidades, com o olhar atento aos pequenos gestos, àquilo que não está dito, ou está dito em tom muito baixo. A professoracoordenadora e as estudantes bolsistas da universidade vêm para dentro da escola, assim como as professoras da escola passam a frequentar a universidade. O grupo de pesquisa conversa com professores e estudantes, funcionários, pais, diretores; atua em seus vários territórios, participa dos movimentos, sente na pele suas tramas e dramas, é afetado com os mais diversos acontecimentos de todos os dias. Tais estratégias são registradas em diários de campo (LOURAU, 1993), como é possível ver na escrita de uma professora de uma escola parceira:

"Com esta metodologia, a intervenção começa em nós mesmos, por meio de leituras e discussões de múltiplas referências teórico-metodológicas [...]. Os pesquisadores começam problematizando o próprio modo de pensar ocidental, marcado pela representação, colocam em discussão a noção de conhecer, de aprender e de ensinar... Os novos conceitos e estudos nos intrigavam ou provocavam um certo desconforto ou mesmo incômodo. Afinal, fomos percebendo que conhecer era sair do lugar, mudar, ter outras atitudes, pensar diferente. Vimos na pele que explicar exaustivamente, como havia aprendido, não ajuda o aluno a aprender, a conhecer. Problematizar era um conceito importante que precisava ser incorporado".

Em trabalhos anteriores, multiplicamos registros de diários, com suas tessituras fragmentárias (DIAS, 2016). Problematizar, encontrar-se e conversar é um dispositivo estratégico que intensifica relações de força para que se possa ganhar terreno no entrelugar e nos aproximar de nós mesmos, de nossos gestos formativos que veiculam escritas, sensações, fazeres, modos de formar - algo próximo do que foi anteriormente caracterizado via a anarqueologia de Michel Foucault.

O diário é apreendido pela análise institucional e pela pesquisa-intervenção como possibilidade de desnaturalizar o que acontece e criar outros sentidos para fazeres e dizeres. Aqui, o diário não tem sentido próprio nem figurado, já que se faz implicado, remetendo às muitas situações abordadas em permanente intensidade. O diário como método (ou o diário e o método) trabalha(m) na tessitura das bordas, das brechas, lá onde a forma deixa de ser o que foi em algum momento naturalizado. Fazer vibrar essas bordas em um processo de contágio, abrir o diário para suas intensidades, trabalhar mais nas misturas que o compõem e menos em uma (suposta) pureza parecem ser potentes indícios político-formativos para que um diário singular não se dissocie de sua face coletiva. Cada fragmento de diário, mais do que ser fragmento, é a expressão de uma ação que se constitui em práticas efetivas abertas às intensidades e às diferenças. Trata-se de reverter 
o trabalho do diário, tomando-o longe do padrão para poder tratá-lo como mais próximo à alteridade, aos processos éticos, estéticos e políticos. Com isso, mostramos que escrever, fazer e dizer correspondem a uma política formativa pela qual se apreende uma dimensão experiencial, em exercícios concretos, e, também, uma dimensão expressiva que abre um entrelugar e um entretempo para forjar experiências modificadoras de si - efeitos dos encontros e conversas que emergem da atitude de habitar, sem hábito, um território e torná-lo visível (DIAS; RODRIGUES, 2019). Assim, a interrupção como sentido e a ruptura como forma nos forçam a pensar que os fragmentos de diário não são textos inacabados; antes, abrem uma outra modalidade de acabamento: aquele que está em jogo na espera, na problematização ou em alguma afirmação irredutível de espreitar e acolher o desconhecido sem o reter/deter. Nessa linha, nosso modo de trabalhar problematiza

o lugar do aluno-professor solucionador de problemas, tensionando os postulados hegemônicos da formação, como aquele que faz funcionar a máquina de propagação da informação e da explicação. O lugar comum da explicação comporta dois âmbitos indissociados. Um produz certo conforto no aprender. O aluno sente-se atendido com a explicação do mestre, produzindo um consenso. Outro âmbito, da explicação, freia o esforço do pensamento, pois, quando o professor explica, ao mesmo tempo que diz a resposta, ele forja no aluno a impossibilidade de pensar por si. Nessa perspectiva, a explicação que comporta a resposta embota o processo de invenção de problemas, muito importante para uma formação inventiva (DIAS, 2011: 257)

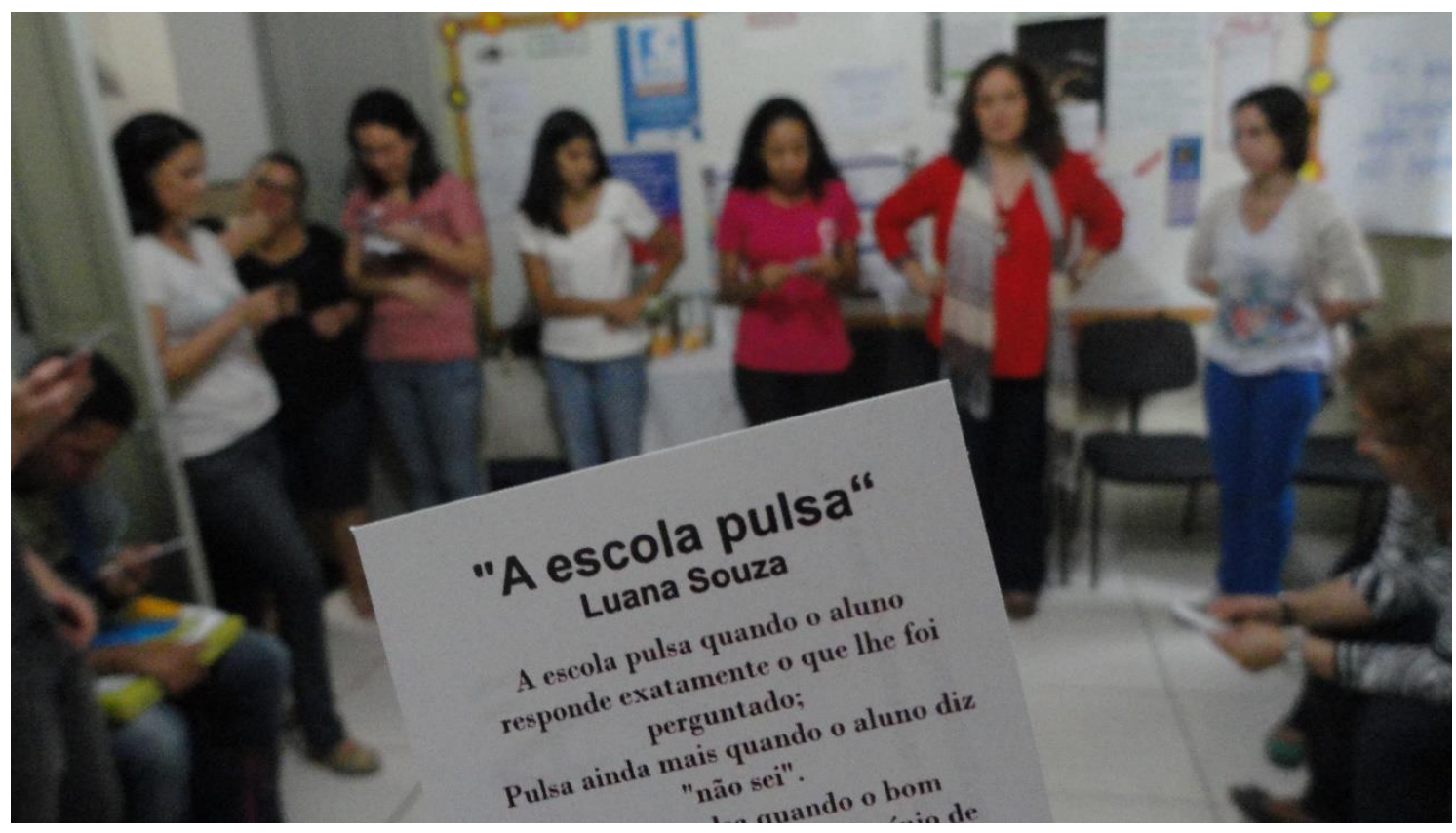

Atividade realizada pelas bolsistas de Iniciação à docência no Colégio Estadual Conselheiro Macedo Soares 
Com tal modo de articular universidade e escola básica, na pesquisa-intervenção fazemos um exercício de colocar a atenção no que se passa, no que acontece no presente, no sentido de fazer ver e falar, de analisar os processos do território escolar em situação coletiva. A proposta é a de dar visibilidade às forças, àquilo que é potência de transformação. Por isso, optamos por realizar, com a escola básica, projetos desenvolvidos pelas bolsistas e supervisionados por professoras da escola: "visibilidades e resistência"; "conexão Macedo"”; "expressão e movimento"; "arte ambiente alteridade". Supervisionar e orientar estes trabalhos afirma a singularidade de encontrar e conversar, como podemos ver nas palavras de uma professora parceira:

"Fazer parte da supervisão requer orientar cada grupo sem direcionar, mas negociando e intervindo. A palavra seria observar sem pensar aprioristicamente o que funcionaria pela minha experiência como professora. Isso é tenso, mas fica guardado. Já vemos a importância do grau de abertura que o projeto requer. Junto com este grau de abertura, a biblioteca composta por ensaios, textos e filmes que lemos e levamos como questões nas reuniões, é um capítulo à parte no projeto. Eles dialogam constantemente conosco e suas leituras não acabam quando o livro termina, ficam reverberando em nós, produzindo efeitos sonoros".

Junto com esta fala, reverberam as palavras das bolsistas:

"A pesquisa me ajuda a ter mais atenção ao presente e a perceber a noção de que não existe receita de bolo para lidar com as situações do cotidiano escolar. Abre-me os olhos para desnaturalizar, aprender a desaprender para tentar evitar atuar por representações em minhas práticas".

Um processo instituinte, que marca como foi importante aprender com Lourau (1993: 11) que "a instituição não é uma coisa observável, mas uma dinâmica contraditória construindo-se na história e no tempo”. Nesta pesquisa-intervenção experimentamos o movimento constante da instituição, em que forças instituídas lutam com forças instituintes. Ler, estudar, escrever, pensar, encontrar-se e conversar regularmente na escola, criar espaços de pesquisa, estabelecer com a direção reuniões periódicas, abertas aos professores, para discutir e analisar a escola básica, propor projetos com os alunos em que se desloca do método "faça como eu" para o "faça comigo" (DIAS, 2011) são, com certeza, forças que mexem com uma escola instituída, contraditoriamente, para não pensar, para não analisar a si própria, para não inventar nada.

Vamos todas, estudantes-professoras e professoras, aprendendo que pesquisar, intervir, conhecer, transformar fazem parte do mesmo processo. Não há separações, binarismos, mas desnaturalizações, problematizações que abrem para as multiplicidades e, ao mesmo tempo, para a singularização. A intervenção ocorre no grupo, na produção 
de outras subjetividades; desestabiliza aquilo que está dado, incomoda o instituído, provoca o pensamento a pensar, a sair das vias únicas, a experimentar a liberdade, a autogestão (LOURAU, 1993), a possibilidade de escolher, de exercer práticas coletivas, de constituir o si e o mundo. A intervenção continua em nós, sempre em formação, como vemos expresso em diários de pesquisa:

Era preciso uma abertura do grupo de pesquisa, por menor que fosse, para a nova experiência. E esta foi acontecendo também no processo, na medida em que fomos convivendo, conhecendo novos autores, novos conceitos-ferramentas para a nossa lida cotidiana. $O$ que os autores, teóricos e práticos, cientistas ou artistas, as múltiplas referências desta pesquisa, nossas conversas e encontros têm nos dito, nos forçado a pensar, a sentir e agir? Desde o início vimos que se não estivermos abertos para ouvir, para aprender, para pensar diferente, não existe pesquisa-intervenção...e nem pode existir vida autônoma, livre. Pode? Abrir-se para esta experiência de pesquisa nos permitiu ver outras possibilidades de trabalhar, de pensar a vida, de conhecer, de fazer ciência, de inventar o mundo e a nós mesmos.

[...]

Hoje resolvi fazer uma experiência nas minhas aulas da $2^{a}$ série. A ideia era deixar para trás as verdades fechadas, e entrar em sala sem expectativa, deixando fluir o acontecimento. Foi uma sensação estranha, com quase 30 anos de magistério, me sentir uma novata, entrando na sala pela primeira vez. Não sabia o que poderia acontecer, estava só aberta para o imprevisível. Experimentei a leveza, mas também um pouco de insegurança, pois embora afetada com as ideias novas, não sabia até que ponto estavam incorporadas. Queria experimentar "o faça comigo" e sair do "faça como eu", e estar no "entre" como propunha Rosimeri. Havia preparado a aula, mas não ensaiado direito como ensinou Deleuze. A técnica, copiei da Shirley que havia feito com os professores, no ano passado. Trouxe uma caixinha com frases dentro de envelopes coloridos. Como meu primeiro assunto era Iluminismo aproveitei temas como liberdade, cidadania, igualdade e outros sobre relacionamentos, etc. Com os alunos em círculo, falei brevemente sobre a proposta: Uma bolinha vai passar de mão em mão, enquanto ouvem uma música, quando ela parar o aluno ou aluna virá até a mesa, vai pegar um envelope, ler e opinar sobre o tema. Perguntei se alguém poderia ficar responsável pela música de um celular. Na semana anterior havíamos discutido sobre o uso do celular em sala, mas disse brevemente que aquele era um outro uso, um uso coletivo, necessário para o desenvolvimento da aula. Foi interessante vê-los discutir um pouco sobre o som, resolvendo entre eles, sobre o melhor tipo de música. Estavam meio envergonhados, mas aos poucos foram se abrindo para o debate. Procurei ficar quieta, não opinar, mesmo quando a bolinha parava em mim. Numa das salas me questionaram por que eu não respondia. Disse que naquele jogo era importante eles falarem o que pensavam. Segurei-me para não dar nenhuma lição de moral, quando o tumulto se anunciava. Deixei acontecer, ou melhor, me deixei experimentar o acontecimento. Algumas vezes falava algo ou lançava uma questão só para provocaro debate. Uns 15 minutos antes de terminar a aula, pedi para comentarem sobre aquela experiência. Alguns não queriam. Houve um pouco de barulho. Falei então o quanto importavam as suas ideias e sensações, que elas precisavam ser registradas. Que agora precisavam do silêncio, quietude para ouvirem a si próprios, para poder pensar melhor e escrever. Foi muito bom experimentar o silêncio e a escrita dos alunos. Ninguém pediu para sair ou fez uso do seu celular... (DIAS; PELUSO, UCHÔA, 2013: 10)

"Aqui neste entrelugar, bolsistas, supervisoras e coordenadora se encontram, conversam, experimentam, estudam permitindo se afetar com as relações, com os conceitos, com as práticas. É uma intervenção, sem dúvida, na escola e na formação, 
tanto das estudantes quanto das professoras, tanto da escola básica como da universidade. É, sobretudo, uma intervenção em nós. E, acompanhamos os processos, colocando em análise o que acontece dentro e fora de nós, coletivamente".

O eixo de intervenção da pesquisa se delineia quando fazemos o mergulho no plano implicacional, plano da experiência, onde conhecer e fazer tornam-se inseparáveis. Acontece uma desnaturalização da escola, levando em conta o conjunto das condições da pesquisa e da instituição (DIAS, 2012a). Tensionamos o instituído o tempo todo, com as ferramentas conceituais e as estratégias propostas pelos sentidos da problematização e da formação perspectivada pela invenção. Vale lembrar que a intervenção não se dá num único sentido, pois ela é um mergulho na situação concreta e seu desafio é tornar visível a experiência, sem representação. É uma mistura do que se anuncia/enuncia com o que se pratica. Com isso, o que criamos é uma política de trabalho, uma estilística, uma estética da existência (FOUCAULT, 2004a).

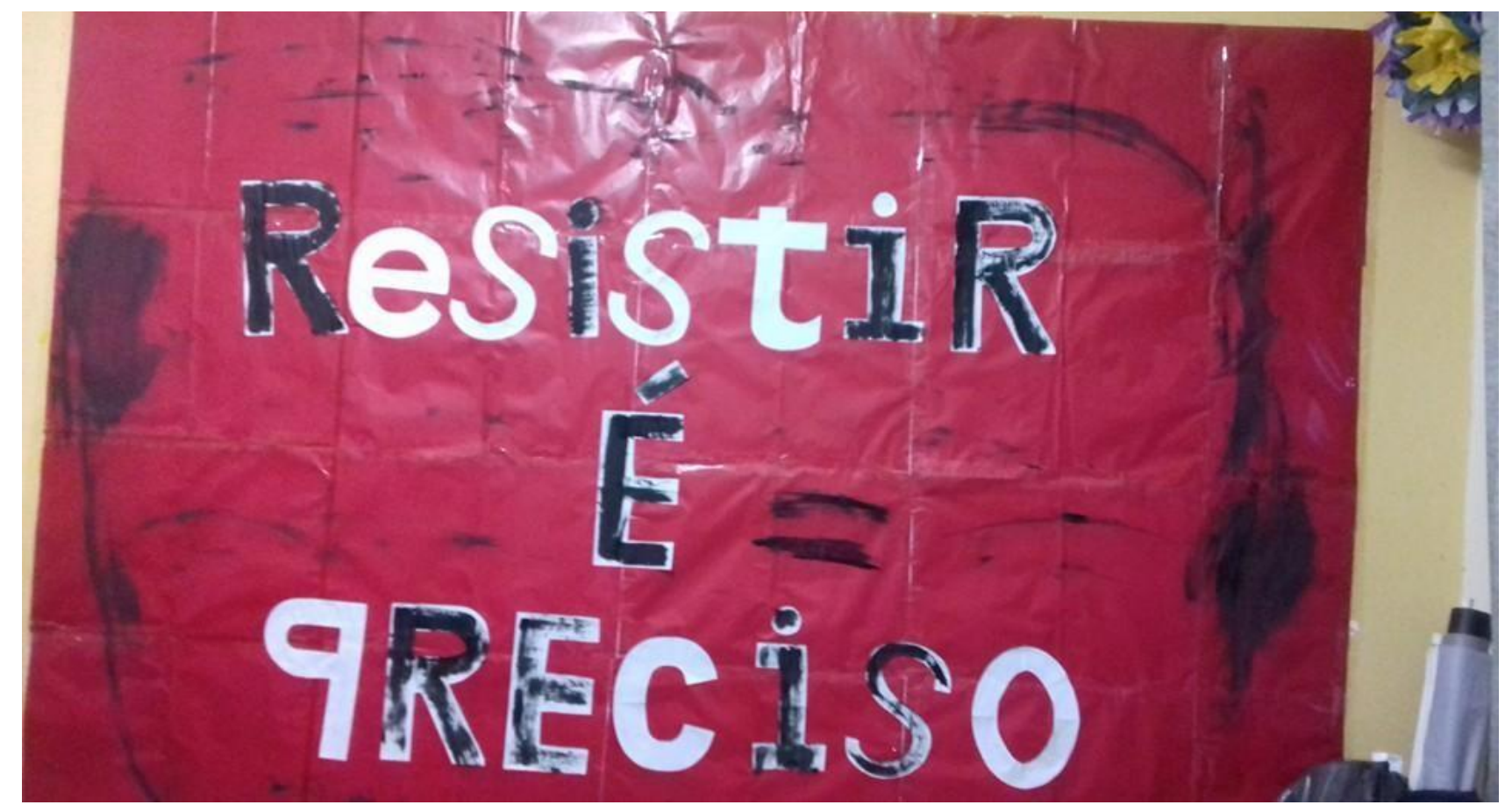

Mural da sala de pesquisa do Colégio Estadual Conselheiro Macedo Soares

\section{Considerações finais}

Na aula de 17 de fevereiro de 1982, do curso A hermenêutica do sujeito, Foucault (2004a: 306) evoca o quanto, no presente, nos referimos à necessidade de construir uma "ética do eu" sem, todavia, chegar a dar-lhe um conteúdo preciso. Parece-lhe (e também a nós) que essa impossibilidade decorre, ao menos em parte, do fato de o Ocidente ter 
conservado, no que tange a tal problema, apenas dois modelos: o da epistrophé platônica, que aponta, via reminiscência, para um outro mundo, de idealidades e perfeições - saída (nihilista) para nossas decepções neste mundo - e o da exegese cristã, ininterrupta decifração de nossos desejos, voltada a vasculhar a profundidade de uma alma invariavelmente sujeita a tentações - alma-sujeito essa à qual se deveria, com base na obediência e na culpa, renunciar (neste mundo) para alcançar a salvação (no outro).

Além desses dois caminhos, resta-nos - Foucault também o diz, em outro momento (6 de janeiro de 1982, primeira hora) - a objetivação científico-tecnocráticoprofissionalizada, cujos começos remontam a um "momento cartesiano" fundador de nossa modernidade, o qual cinde o plano epistemológico do plano ético: o sujeito pode então conhecer sem que, para tanto, seu ser de sujeito precise ser transformado, pois lhe bastam regras formais de método e qualificações pedagógico-culturais. "Tal como é, o sujeito é capaz de verdade", já que esta não mais concerne "ao sujeito no seu ser" (FOUCAULT, 2004a: 22-23).

Quanto ao problema contemporâneo da formação, tanto os modelos (platônico e cristão) de conversão a si quanto a ausência de aspiração ética ligada ao momento cartesiano parecem veicular unicamente impasses: “os professores não são mais idealistas como eram antes, é preciso reencantá-los"; "fascinados que estão com o dinheiro, carecem de esforço e dedicação, é necessário reorientá-los"; "são mal formados, já que, hoje, somente quem não estuda quer ser professor, e é preciso fornecer-lhes instrumentos metodológicos e técnicos renovados", etc.

Como não é difícil perceber, seja a formação platônica seja a cristã apontam a transcendências correlacionáveis a guias, leis, regulações especializadas/especializantes. Prescindir do cuidado de si, por sua vez, implica aguardar pelo tecnocrata do momento, pronto a tudo solucionar à base de técnicas e/ou de algum grau (degrau?) adicional na hierarquia das "certificações” pedagógicas.

Já o que Foucault (2004a: 314) apelida "modelo do meio" - não no intuito de conciliação, mas por diagnosticar seu abandono -, ou seja, o cuidado de si helenísticoromano, poderia associar-se ao que, desde o início deste artigo, designamos como "formação inventiva". Tal formação aposta na construção coletiva e autonomizadora de um "equipamento" (paraskeué) que nos faculte seja retornar a nós mesmos como porto seguro, seja - o que é bem mais interessante - construir a nós mesmos durante toda a vida. A respeito dessa oscilação entre retorno e construção, ouçamos Foucault, que por sinal não a soluciona, já que confia na força do pensamento de seus ouvintes e/ou leitores: 
"O que significa retornar a si? Que círculo é esse, que circuito, que dobra é esta que devemos operar relativamente a algo que, contudo, não nos é dado, senão apenas prometido ao termo de nossa vida?" (FOUCAULT, 2004a: 302).

Em tais práticas e exercícios - pois é disso que se trata no "modelo do meio" -, pouco a pouco desaparecem os lamentos, visto que há sempre algo a fazer: algo facultativo, alegre, não obrigatório, porém inevitavelmente voltado a engendrar um cotidiano libertário. E o que seria esse cotidiano? Ousamos dizer que seria aquele que vê, na arte (artesania?) de constituir, hoje, uma ética do eu, "uma tarefa urgente, fundamental, politicamente indispensável, se for verdade que, afinal, não há outro ponto [...] de resistência ao poder político senão na relação de si para consigo" (FOUCAULT, 2004a:.306).

Do que precisamos para nos engajar nessa tarefa, política e eticamente essencial? De algo que esteja sempre à mão, como parte integrante de nosso corpo e nossa prática, servindo de armadura para os embates do dia a dia, neste mundo. Pois, como vimos, paraskeuázein significa "preparar para", portanto "formar", e pode sempre distanciar-se de nihilismos, crenças obedientes e tecnocracias, integrando-se, alternativamente, a artes libertárias de viver, pensar, agir e ser....neste mundo.

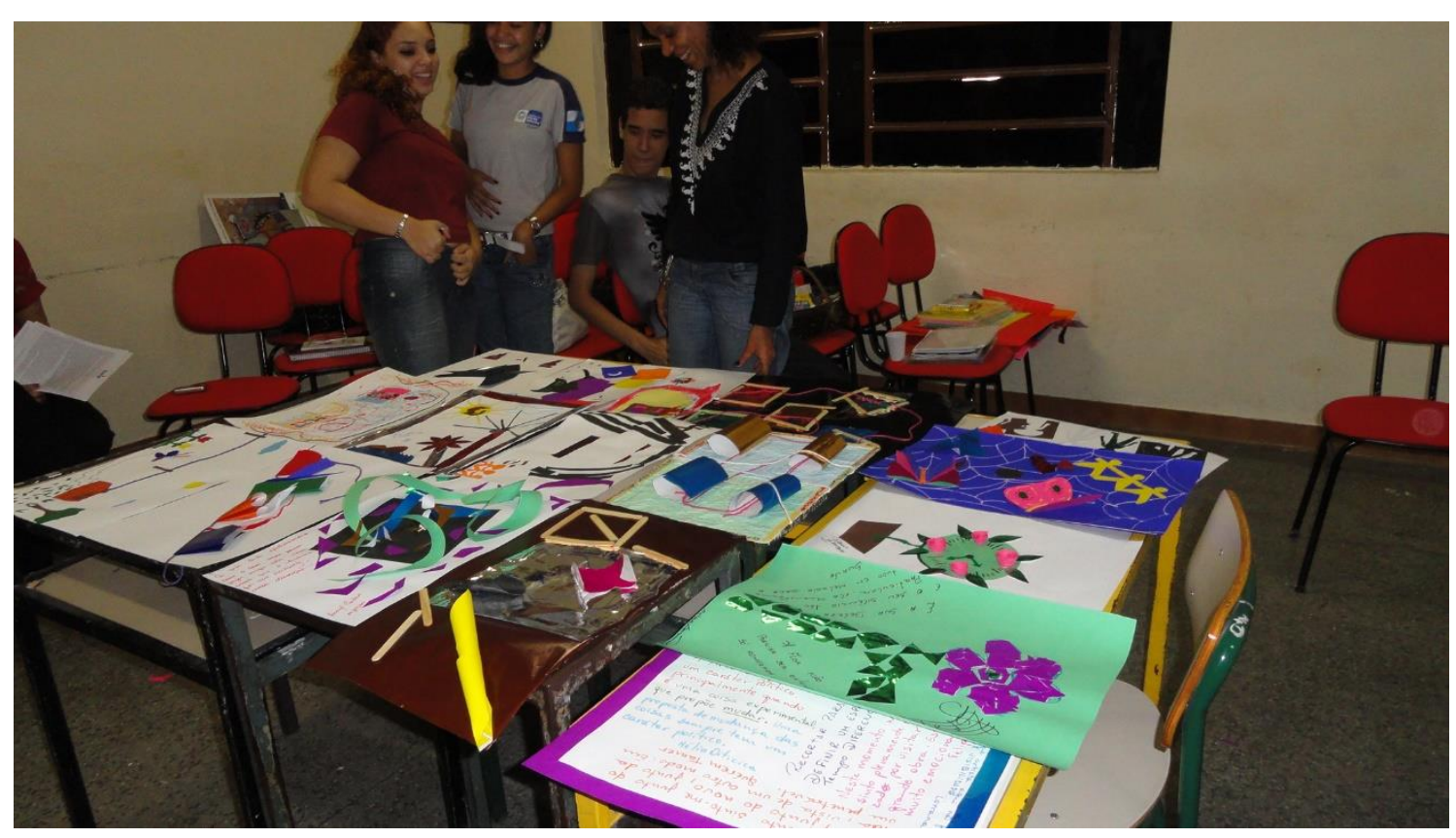

Oficina de formação inventiva de professores no Colégio Macedo Soares 


\section{Referências}

CHEVALLIER, Philippe. Que quer dizer fazer uma história das problematizações? Mnemosine. Rio de Janeiro, v. 11, $\mathrm{n}^{\circ}$ 2, 2015, p. 298-312. Disponível em: http://www.mnemosine.com.br/ojs/index.php/mnemosine/article/view/455/377 Acesso em 22 out 2019.

DELEUZE, Gilles. Proust e os signos. Rio de Janeiro: Forense Universitária, 2003.

DELEUZE, Gilles. O que é um dispositivo? In: DELEUZE, G. Dois regimes de loucos. Rio de Janeiro: Ed. 34, 2016. pp. 359-369.

DELEUZE, Gilles; GUATTARI, Felix. Mil Platôs: capitalismo e esquizofrenia. Vol. 1. Rio de Janeiro: Editora 34, 2004a.

DELEUZE, Gilles; GUATTARI, Felix. O que é filosofia? Rio de Janeiro: Ed. 34, 2004b.

DIAS, Rosimeri de Oliveira. Fragmentos de diário de campo, escrita e devir texto. In: CALLAI, Cris; RIBETTO, Anelice. Uma escrita acadêmica outra: ensaios, experiências e invenções. Rio de Janeiro: FAPERJ/Lamparina, 2016, p. 111-123.

DIAS, Rosimeri de Oliveira. Produção da vida nos territórios escolares: entre universidade e escola básica. Psicol. Soc., Belo Horizonte, v. 24, n. spe, 2012a, p. 67-75. Disponível em http://www.scielo.br/scielo.php?script=sci_arttext\&pid=S0102-

$71822012000400011 \& \operatorname{lng}=\mathrm{pt} \& \mathrm{nrm}=$ iso $\quad$ Acesso em 01 maio 2020. http://dx.doi.org/10.1590/S0102-71822012000400011.

DIAS, Rosimeri de Oliveira. Formação inventiva de professores. Rio de Janeiro: Lamparina, 2012b.

DIAS, Rosimeri de Oliveira. Deslocamentos na formação de professores: aprendizagem de adultos, experiência e políticas cognitivas. Rio de Janeiro: Lamparina, 2011.

DIAS, Rosimeri de Oliveira; PELUSO, Marilena Reis; UCHÔA, Márcia Helena. Conversas entre micropolítica e formação inventiva de professores. Mnemosine. Volume 9, $\mathrm{n}^{\mathrm{o}}$ 1. Rio de Janeiro: UERJ, 2013, p224-237. Disponível em: http://www.mnemosine.com.br/ojs/index.php/mnemosine/article/view/283/pdf_2 66 Acesso em 11 out 2019.

DIAS, Rosimeri de Oliveira; RODRIGUES, Heliana de Barros Conde (orgs.). Escritas de si: Escutas, cartas e formação inventiva de professores entre universidade $\mathrm{e}$ escola básica. Rio de Janeiro: FAPERJ/Lamparina, 2019.

FEYERABEND, Paul. Contra o método. Rio de Janeiro: Francisco Alves, 1977.

FOUCAULT, Michel. História da sexualidade 2: o uso dos prazeres. $7^{\mathrm{a}}$ ed. Rio de Janeiro: Graal, 1994a.

FOUCAULT, Michel. Entretien avec Michel Foucault. In: FOUCAULT, Michel. Dits et Écrits, vol. IV. Paris: Gallimard, 1994b.

FOUCAULT, Michel. A hermenêutica do sujeito. São Paulo: Martins Fontes, 2004a.

FOUCAULT, Michel. Polêmica, política e problematizações. In: Ditos e escritos V: ética, sexualidade, política. Rio de Janeiro: Forense Universitária, 2004b. pp. 225-233 
FOUCAULT, Michel. Sobre a história da sexualidade. In: FOUCAULT, M. Microfísica do poder. 26 ${ }^{\mathrm{a}}$ ed. Rio de Janeiro: Graal, 2008. pp. 243-276.

FOUCAULT, Michel. O governo de si e dos outros. São Paulo: Martins Fontes, 2010.

FOUCAULT, Michel. A coragem da verdade. São Paulo: Martins Fontes, 2011.

FOUCAULT, Michel. Do governo dos vivos. São Paulo: Martins Fontes, 2014a.

FOUCAULT, Michel. Sobre a genealogia da ética: um resumo do trabalho em curso. In: FOUCAULT, M. Ditos e escritos IX: genealogia da ética, subjetividade e sexualidade. Rio de Janeiro: Forense Universitária, 2014b, p. 214-237.

GROS, Frédéric. Problematização. Mnemosine. Rio de Janeiro, v. 11, nº 2, 2015, p. 296297. http://www.mnemosine.com.br/ojs/index.php/mnemosine/article/view/454/376 Acesso em 22 out 2017.

GROS, Frédéric. Situação do Curso. In: FOUCAULT, Michel. Hermenêutica do Sujeito. São Paulo: Martins Fontes, 2004, p. 613-662.

HADOT, Pierre. Exercícios espirituais e filosofia antiga. São Paulo: É realizações, 2014.

JAEGER, Werner. Paideia - a formação do homem grego. São Paulo: Martins Fontes, 2001.

KASTRUP, Virgínia. A invenção de si e do mundo: uma introdução do tempo e do coletivo no estudo da cognição. São Paulo: Papirus, 1999.

LOURAU, René. Análise Institucional e práticas de pesquisa. Rio de Janeiro: NAPE/UERJ, 1993.

PASSOS, Eduardo; KASTRUP, Virgínia; ESCÓSSIA, Liliana (orgs.). Pistas do método da cartografia: pesquisa-intervenção e produção de subjetividade. Porto Alegre: Sulina, 2009.

PRADO JUNIOR, Bento. A educação depois de 1968, ou cem anos de ilusão. In: CHAUI, Marilena; TRAGTENBERG, M.; ROMANO, R.; PRADO JUNIOR, B. Descaminhos da educação pós 68. São Paulo: Brasiliense, 1980, p. 9-30.

ROCHA, Marisa Lopes. Falando de pesquisa-intervenção na formação escolar. In: DIAS, Rosimeri de Oliveira. Formação inventiva de professores. Rio de Janeiro: Lamparina, 2012, p. 42-51.

RODRIGUES, Heliana de Barros Conde. As subjetividades em revolta: institucionalismo francês e novas análises. No Prelo.

Rosimeri de Oliveira Dias

Professora Adjunta do Departamento de Educação e do Programa de Pós-Graduação em Educação Processos Formativos e Desigualdades Sociais, da Faculdade de Formação de Professores de São Gonçalo, da Universidade do Estado do Rio de Janeiro.

Procientista da UERJ e Jovem Cientista do Nosso Estado FAPERJ Coordenadora do Subprojeto de Pedagogia da FFP/PIBID/CAPES/UERJ (2011-2018) E-mail:rosimeri.dias@uol.com.br 
Heliana de Barros Conde Rodrigues
Professora Associada do Departamento de Psicologia Social e Institucional e do
Programa de Pós-Graduação em Políticas Públicas e Formação Humana da
Universidade do Estado do Rio de Janeiro.
Procientista da UERJ
E-mail: helianaconde@uol.com.br

\begin{abstract}
${ }^{1}$ Uma excelente síntese dessas contestações pode ser encontrada em PRADO JUNIOR, 1980.
2 Tal desdobramento, em Foucault, ocorre notadamente em seu último curso, ministrado em 1984 e sugestivamente intitulado A coragem da verdade (FOUCAULT, 2011). Seguiremos outro caminho, que avaliamos como igualmente corajoso.

${ }^{3}$ Cumpre lembrar que ao propor seu procedimento anarqueológico, Foucault (2014a: 73) recomenda aos ouvintes do curso Do governo dos vivos, datado de 1980, a leitura de Contra o método, de Paul Feyerabend, então recém-editado na França, pela Seuil. Para a edição brasileira, ver FEYERABEND, 1977.

${ }^{4}$ Também os estoicos serão abordados, porém somente na aula de 17 de fevereiro, que não apresentaremos.

${ }^{5}$ Esse suplemento, esse "a mais", ao ver de Demetrius, só se justifica em uma alma já retirada, ao abrigo na região de segurança que lhe fornece a sabedoria. Caso contrário, ele o denuncia, critica e rejeita.
\end{abstract}

${ }^{6}$ Acerca da noção grega de paideía, consultar JAEGER, 2001.

7 Aqui nos referimos aos projetos coordenados por Rosimeri de Oliveira Dias, desde 2008, na Faculdade de Formação de Professores de São Gonçalo em parceria com o Colégio Estadual Conselheiro Macedo Soares e o CIEP Municipalizado 411, sobre formação inventiva de professores. São eles: "Formação inventiva: pesquisa, experiência e aprendizagem de adultos na formação de professores" (contemplada com Auxílio Instalação/FAPERJ/ 2008); "Formação inventiva: experiência e políticas cognitivas na formação de professores" (contemplada com APQ1/FAPERJ/2009); "Formação inventiva de professores e políticas de cognição como dispositivos para a criação do conselho escolar do Colégio Estadual Conselheiro Macedo Soares" (contemplada com o Edital FAPERJ No 14/2009); "Por uma expansão de territórios de pensamento entre universidade e escola básica" (Contemplada com APQ1/FAPERJ/2012) e "Uma aposta ética, estética e política para expandir territórios de pensamento entre universidade e escola básica" (Contemplada com o Edital FAPERJ 34/2013 - Melhoria do Ensino). Como efeito direto das pesquisas, foi lançado o livro "Formação inventiva de professores", em dezembro de 2012. Tal livro foi contemplado com APQ3/FAPERJ/2011. Com as pesquisas citadas, foi possível a criação e manutenção, até 2018, de duas salas de pesquisa nas escolas básicas parceiras: Colégio Estadual Conselheiro Macedo Soares (CECMS) e CIEP Brizolão 411 (CIEP 411). Estas salas acolheram os estudantes da graduação e da pós-graduação da FFP e suas atividades de Iniciação à docência, de extensão e de pesquisa, que acontecem semanalmente. A presente pesquisa, inclusive, insere-se no percurso de produção de outras atividades de caráter institucional em que se faz deslocar a noção de formação inventiva de professores, a saber: "Articulando Universidade e a Escola Básica no Leste Fluminense: investigando o estágio docente como política de formação inicial de professores PRODOCÊNCIA/CAPES/2008", "Interação Universidade-Escola: vivenciando a formação docente PRODOCÊNCIA/CAPES/2011" e "Saber escolar e formação docente na Educação Básica PIBID/CAPES/UERJ". Nesta última, coordenado por Rosimeri Dias, situa-se o Subprojeto de Pedagogia da FFP/UERJ, entre 2011 e 2018, que foi desenvolvido nas escolas básicas parceiras. É importante destacar que nos últimos quatro anos de PIBID existiram, ligados aos projetos, 30 bolsistas de Iniciação à Docência e 6 bolsistas supervisores, professoras das escolas parceiras (para maiores detalhes: www.ofip.org e https://www.facebook.com/pibidcursodepedagogiaffpuerj)

${ }^{8}$ Nome abreviado de uma das escolas parceiras. 